\title{
Accounting
}

\section{The association between cost-standard setting and work performance: The role of information asymmetry and goal complexity}

\author{
Saad Salih Hussein ${ }^{a^{*}}$
}

a Assistant professor, Department of accounting, Tikrit university, Iraq

\section{H R O N I C L E}

\section{Article history:}

Received: January 12, 2021

Received in revised format:

April 82021

Accepted: April 22, 2021

Available online:

April 22, 2021

Keywords:

Participation in cost standard-setting (PSS)

Work performance (WP)

Information asymmetry (IA)

Goal complexity $(G C)$

\section{A B S T R A C T}

This paper is an empirical testing of the association between Cost Standard-Setting (PSS) on Work Performance (WP), mediated With Information Asymmetry (IA), and Goal Complexity (GC). It is a rule of thumb that PSS setting can lower the level of IA and GC between the managers and the employees and leads to better WP. The present work uses a path model to measure the direct, indirect, and spurious effect between the dependent and independent variables of this study. Data were collected from ten corporate firms in Iraq via a pre-designed questionnaire survey, the questionnaire forms were distributed randomly to the firm's top management personnel, departmental managers, engineers, accountants, and administrators who are involved in PSS. Around 350 forms were distributed for data collection, however, only 198 forms were considered for this analysis, the rest of the forms were discarded due to incompleteness or missing values. The findings of the study showed a significant direct effect of PSS on WP. Likewise, there was clear evidence of an indirect effect via the mediating variables (IA and GC). The influence of IA and GC confirms the strong association between the independent variable (PSS) on the dependent variable (WP).

\section{Introduction}

Cost standards are a predetermined target that should be met at the end of the accounting period. The researcher believes that communication among the employees and involvement in setting the target leads to simplifying GC and lowering the level of IA and subsequently reaching higher WP. On the other hand, less communication and less involvement in target setting in firms can cause less motivation among the employees to attain the target and then raising the level of GC with a higher level of IA in the firms' organizational hierarchy which eventually impacts employee WP negatively. Managerial accounting literature has a rich history in examining participation and performance (Lau and Eggleton, 2003; Yucel and Gunluk, 2007; Leach-Lopez et al., 2008 \& 2009; Ozer and Yilmaz, 2011; Odia, 2013; Mah'd et al., 2013; Mazzioni et al., 2014; Hussein et al., 2016; Ahn et al., 2018; Sim and Utami, 2018; Berdicchia and Masino, 2019; Zainuddin and Isa, 2019; Lunardi et al., 2020). For instance, Lau and Eggleton (2003) stated that through participation, firms can set more suitable and achievable goals. Yucel and Gunluk (2007) debated that psychological theories suggest that participation is related to performance through identification and egoinvolvement with the budget goals. Likewise, Mah'd et: al (2013) suggested that the performance indicators of the respondents in the participation group are significantly better than the performance indicators of the respondents in the centralized group. Sim and Utami (2018) found that participation has a positive significant effect on employees' performance. The results of

* Corresponding author

E-mail address: shussein@tu.edu.iq (S. S. Hussein) 
Berdicchia and Masino (2019) suggest that participation does help to create the conditions that encourage workers to craft their jobs then increase performance. The researcher contributes to the existing literature by introducing and examining the relationship between PSS and WP through GC and IA for a sample of Iraqi corporate firms, the study, therefore, used a path model to explain the direct and indirect effect between PSS and WP. For more efficient WP in firms, modern management accounting techniques are used together with traditional management techniques such as budgeting and standard costing (Waweru et al., 2005).

The present study is similar to Leach-Lopez et al. (2007) and Hussein et al. (2016) by using mediating variables to explain the effect of participation on performance in presence of mediating variables. Nevertheless, the present study differs from other studies by using a sample from Iraqi corporate firms. The importance of selecting this sector to study is to shed a light on what is the potential of the Iraqi economy aside from the oil sector. It is a fact that the oil sector is currently contributing more than $90 \%$ to the Iraqi GDP; which may make the Iraqi economy fluctuate based on the price change of the crude oil market. Therefore, it is necessary to examine the scenario of non-oil sectors and examine what variables affect the WP in the Iraqi corporate firms. The results of this study came to confirm the positive association between PSS and WP through GC and IA.

The Iraqi industrial sector reserves its important position because it is the second-largest GDP-contribution sector, where the oil sector (the largest contribution sector) presents a high risk to cover the national liabilities especially when there is a risk of price change of crude oil in the international markets. The remainder of this paper is organized as the following; section two deals with the theory and hypothesis development, while section three presents data and methodology. Section four discusses the study's empirical testing and results. Section five provides the concluding remarks shedding light on the limitations of the study and finally the suggestions for future research.

\section{Theory and hypothesis-development}

Firms in emerging economies need to focus on accounting standard setting as an improvement element to reach the highest WP. The role of IA and GC can also play a vital role in achieving the predetermined target. The present study is a maiden attempt to measure the impact of participation in cost accounting setting on WP using two mediating variables: IA and GC in the Iraqi firm's context. The researcher expects that PSS can decrease the level of IA and GC and subsequently have a significant impact on WP. Hence, the researcher's main concern in this paper is to examine the role of the PSS on WP considering IA and GC as mediating variables in ten Iraqi industrial firms. The researcher is proposing a path model to capture both direct and indirect effects of the role of PSS on WP. Path model is presented in Fig. 1.

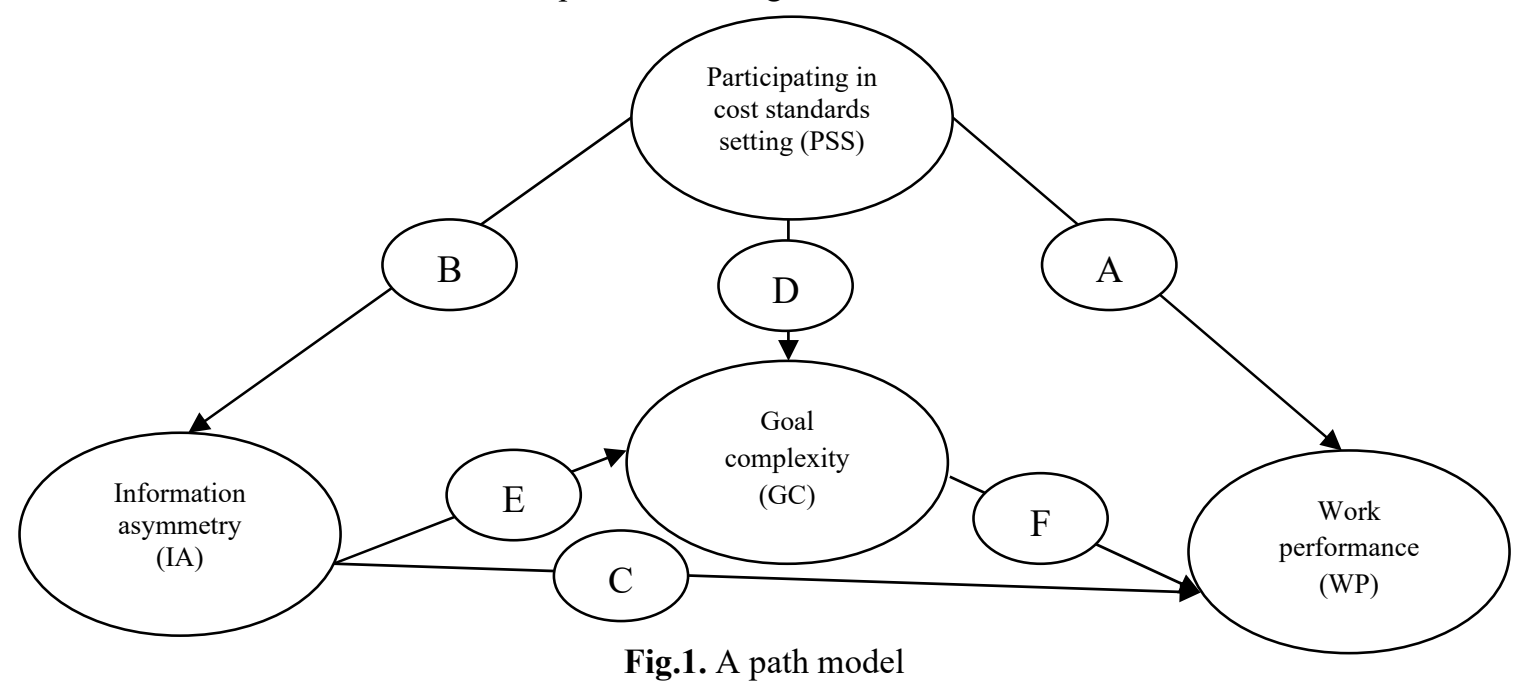

\subsection{The relationship between PSS and WP}

Abundant empirical studies have shown that there is a positive impact of participation on performance. This relationship was investigated on the role of budget participation on managerial performance (Leach-Lopez et al., 2008, 2009; Ozer \& Yilmaz, 2011; Odia, 2013; Mazzioni et al., 2014; Hussein et al., 2016; Sim \& Utami, 2018; Zainuddin \& Isa, 2019; Lunardi et al., 2020). Nonetheless, Cherrington and Cherrington (1973) observed a negative relationship between participation and performance. Likewise, the results of the Jermias and Yigit (2013) study indicate that the direct effect of participation on performance is not statistically significant. In the same vein, the researcher expects that participation in a PSS can enhance WP. For instance, the empirical testing came to confirm that an effective target setting can contribute to employee effective responses, employee 
performance, and organizational performance (Locke, 2004; Smith et al., 1990; Ahn et al., 2018). Ahn et: al (2018) stated that participation in the target setting increases the chances of achieving the target, by rising the commitment (Curral et al., 2017). Based on the above proposition it's to the hypothesis that:

\section{$\mathbf{H}_{1}$ : Participation in standards-setting enhances work performance.}

\subsection{The relationship between $I A$ and $W P$}

Sharing relevant information related to the production process within the firm's personnel is a vital factor in reducing workplace conflict and elevating WP. Information asymmetry in firms occurs when there is no more equivalent information obtained by one party than another (George, 2001). IA refers to a different amount of information and knowledge available in different parties' custody in a particular firm (Akerlof, 1970; James \& Tonye, 2014; Khalid \& Hunjra, 2018). Perhaps one of the reasons behind IA in firms is self-satisfaction (De Faria \& Da Silva, 2013). Mixed results were revealed by scholars regarding the relationship between IA and WP. For instance, researchers found that IA has a positive relationship with firm performance i.e. (Nayyar, 1993; Dusabe et al., 2016; Yuen \& Cheung, 2003; Hu \& Yu, 2010; Kemeiand Kerongo, 2014; Venugopal, 2017; Zainuddin and Isa, 2019; Lunardi et al., 2020). However, Faria and Da Silva (2013) and Machdar et al. (2017) stated that regardless of the position held in a company, they both use IA to set specific goals with slack. Whereas Fitoussi et al. (2009) could not find a connection between IA and participation and then performance. Hence, the second hypothesis of this paper is:

\section{$\mathbf{H}_{2}$ : Information asymmetry has a positive relationship with work performance.}

\subsection{The relationship between $G C$ and $W P$}

Usually, targets can vary from too rigid to too loose. Goals that are too rigid may affect employees' motivation to achieve the target, whereas, goals that are too loose can be achieved easily without real effort by the employees, where they lose the challenge and subsequently their motivation. Further, a tight but achievable target may be the best way to motivate the employees and they reach satisfaction when they attain the participative goals. For example, Lau and Eggleton (2003) stated that complex tasks and goals may have a substantial impact on WP. Hui et al. (2013) stated that subjective task complexity and personal goals appear to be important to enhance WP. Likewise, Zacher et al. (2010) stated that employees in high-complexity jobs are positively affected by WP. Kozlowski \& Hults (1986) and Man \& Lam (2003) devoted complex goals stimulate employees' motivation to employ their skills, knowledge, and collaboration with other employees to achieve predetermined goals. Fitoussi et: al, (2009) found that when managers are committed to their goals and have a clear understanding of their role they are expected to perform better. Espedido and Searle (2018) found a direct significant and positive relationship between goal difficulty and creativity which will subsequently lead to better WP. Hardin et al. (2013) participative setting difficult goals directly affect actual performance through employees' commitment to achieving these goals. Nevertheless, Weinberg et: al (2019) found a significant correlation between participants and work but did not enhance WP. Kalkanci et al. (2011) stated that more complex tasks do not lead to better channel coordination. It is therefore to hypothesize that:

\section{$\mathbf{H}_{3}$ : Goal complexity is positively related to work performance.}

\section{Data and methodology}

\subsection{Data and sample}

Data have been collected by using a primary method of data collection (survey) from the employees of ten corporate firms working in Iraq (Appendix 1). The choice of the Iraqi context is justified by it being one of the fastest-growing economies in the developing countries (Business Insider report). The sample of the present study is justified by its contribution to the volume of production and value added (\% of GDP): $2.05 \%^{1}$ (the second-largest sector to the oil sector in Iraq). Moreover, oil-producing countries have faced real crises during the time of decreased crude oil prices. It is, therefore, a necessity to present and give higher intention to the sectors that contribute to the national GDP other than the oil sector. Primary data was collected using a random sampling technique from ten corporate firms in Iraq namely: Light Industrial Company, Alhilal Industrial Company, Iraqi Company for Manufacturing Cartons, Modern Painting Company, Modern Sewing Company, Iraqi Company for Carpet and Furniture, Iraqi National Company for Manufacturing Chemical and Plastic Materials, Pepsi Baghdad Company, Iron and Bicycle Company, Iraqi Company for Manufacturing and Exporting Dates. The forms were distributed from August to October 2019. Only 198 out of 350 forms were retrieved and considered for the analysis. The rest of the forms (omitted) were not completed, wrongly filled out, or left blank. Questionnaire facts are shown in Table 1.

$1 \mathrm{https} / / /$ globaledge.msu.edu/countries/iraq/memo(2016) 
Table 1

The summary of the questionnaire facts

\begin{tabular}{|c|c|c|c|c|c|}
\hline \# & Company name & $\begin{array}{c}\text { Total } \\
\text { number of } \\
\text { employees }\end{array}$ & $\begin{array}{c}\text { Questionnaire } \\
\text { forms } \\
\text { distributed } \\
\end{array}$ & $\begin{array}{l}\text { Questionnaire } \\
\text { forms received } \\
\text { and analyzed }\end{array}$ & $\begin{array}{c}\text { Percentage } \\
\text { of total } \%\end{array}$ \\
\hline 1 & Light Industrial Company & 336 & 35 & 16 & 46 \\
\hline 2 & Alhilal Industrial Company & 203 & 45 & 41 & 91 \\
\hline 3 & Iraqi Company for Manufacturing Cartons & 102 & 35 & 15 & 43 \\
\hline 4 & Modern Painting Company & 147 & 35 & 18 & 51 \\
\hline 5 & Modern Sewing Company & 45 & 30 & 15 & 50 \\
\hline 6 & Iraqi Company for Carpet and Furniture & 55 & 25 & 19 & 76 \\
\hline 7 & Iraqi National Company for Manufacturing Chemical and Plastic Materials & 189 & 35 & 15 & 43 \\
\hline 8 & Pepsi Baghdad Company & 1325 & 40 & 15 & 38 \\
\hline 9 & Iron and Bicycle Company & 143 & 30 & 14 & 47 \\
\hline \multirow[t]{2}{*}{10} & Iraqi Company for Manufacturing and Exporting Dates & 363 & 40 & 30 & 75 \\
\hline & Total & 2908 & 350 & 198 & 57 \\
\hline
\end{tabular}

Note: data was collected from the human resource departments of the respected companies on February 2019.

\subsection{Variable measurement}

For measuring participation in costing standards-settings, we employed a similar tool of measuring budget participation. The measure was based on a seven-point Likert-scale ranging from 1 (strongly disagree) to 7 (strongly agree). The initial usage of this scale was by Milani (1975). This scale was widely used by the researchers: (Brownell, 1983; Chenhall \& Brownell, 1988; Mia, 1989; Nouri \& Parker, 1998; Tsui, 2001; Wanous \& Hudy, 2001; Lau \& Tan, 2003; Hassel \& Cunningham, 2004; Mahjoub \& Halioui, 2012; Hussein et al., 2016). To measure GC a five-point Likert-scale was used ranging from 1 (very little) to 5 (very much). The scale was used by: (Semmer, 1982; Zapf, 1993; Zacher et al., 2010). Again, WP was measured by using a five-point Likert-scale ranging from 1 (needs improvement) to 5 (excellent). This scale is role-based Performance, containing 20 items. The scale was used by (Welbourne et al., 1998; Zacher et al., 2010). Finally, IA was measured by using a seven-point Likert scale ranging from 1 (my superior has much better information) to 7 (I have much better information). This scale was suggested by Chow (1983) and Chow et al. (1988) and later was developed by Dunk (1993) and then used by (Jermias \& Yigit, 2013; Yuen \& Cheung, 2003).

\subsection{Model used}

To measure the direct and indirect effect of participating in costing standards settings on WP with mediating of work complexity the study has considered path model analysis. The superiority of this model over the multiple regression model comes from the ability to capture the effect of the independent variable on the dependent variable with the presence of one or more mediating variables (Luft \& Shields, 2003; Leach-Lopez et al., 2008, 2009, Hussein et al., 2016). Path model can measure both the direct and indirect impact of the (PSS) on (WP) through (WC). The study model is presented here to estimate the direct and indirect path model coefficients.

$$
\begin{aligned}
& \mathrm{WP}_{i}=b_{1} \mathrm{PSS}_{i}+b_{2} \mathrm{IA}_{i}+b_{3} \mathrm{GC}_{i}+e_{i} \\
& \mathrm{GC}_{i}=\beta_{1} \mathrm{PSS}_{i}+\beta_{2} \mathrm{IA}_{i}+\varepsilon_{i} \\
& \mathrm{IA}_{i}=\gamma_{2} \mathrm{PSS}_{i}+v_{i}
\end{aligned}
$$

where WP is work performance; PSS is participating in costing standards settings; IA is IA and GC is goal complexity. The proposed path model is based on many previous studies viz. Nouri and Parker (1998), Leach-Lopez et al., (2008, 2009), and Hussein et al., (2016). By using this path model, the researcher expects to measure the direct and indirect effect of the independent variable on the dependent variable through their coefficients.

\section{Empirical testing and results}

\subsection{Descriptive statistics}

Table 2 illustrates the descriptive statistics of the ten researched companies. The observed Cronbach's alpha value was 0.874 indicating that there is no issue with the data's internal reliability. It is also observed from the table that the minimum value of all the studied variables was 1 and the maximum value was the upper limit of each variable measurement. PSS upper limit was 7, GC is 5, WP is 5, and IA is 7. A look into the table shows that all the variables are presented by their means values, standard deviation, and data skewness. The observed mean statistics of the main variables are measured and found to be for IA is (5.11), PSS (5.08), GC (2.65), and WP (3.99). These values give a hint that the effect is moderate-higher level. Further, the Standard deviation values are: IA (0.47), PSS (1.47), GC (0.68), and WP (0.24). The results, therefore, are consistent with other empirical 
studies' findings i.e. (Eker, 2006; Leach-Lopez et al., 2008; Dakhli, 2010; Rachagan et al., 2013; Owusu et al., 2014; Hussein et al., 2016).

Table 2

Descriptive statistics

\begin{tabular}{|c|c|c|c|c|c|}
\hline Variables & $\begin{array}{c}\text { Minimum } \\
\text { Statistic }\end{array}$ & $\begin{array}{l}\text { Maximum } \\
\text { Statistic }\end{array}$ & $\begin{array}{c}\text { Mean } \\
\text { Statistic }\end{array}$ & $\begin{array}{c}\text { Std. Deviation } \\
\text { Statistic }\end{array}$ & $\begin{array}{c}\text { Skewness } \\
\text { Statistic }\end{array}$ \\
\hline age & 1.00 & 5.00 & 3.13 & 1.03 & -0.040 \\
\hline gender & 1.00 & 2.00 & 1.43 & 0.49 & 0.297 \\
\hline position & 1.00 & 4.00 & 1.80 & 1.18 & 1.011 \\
\hline qualification & 1.00 & 3.00 & 2.28 & 0.71 & -0.461 \\
\hline leangth1 & 1.00 & 5.00 & 3.15 & 1.04 & -0.046 \\
\hline leangth2 & 1.00 & 5.00 & 3.65 & 1.02 & -0.333 \\
\hline IA & 1.00 & 7.00 & 5.11 & 0.47 & -0.489 \\
\hline PSS & 1.00 & 7.00 & 5.08 & 1.47 & -0.409 \\
\hline GC & 1.00 & 5.00 & 2.65 & 0.68 & -0.254 \\
\hline WP & 1.00 & 5.00 & 3.99 & 0.24 & -0.017 \\
\hline
\end{tabular}

\subsection{Inter-correlation results}

Table 3 illustrates the matrix of inter-correlation among the PSS, IA, GC, and WP. A cursory look into the table gives a hint that all the variables are highly correlated. For instance, the correlation between PSS and IA was $(0.865)$ at a $5 \%$ level of significance. Likewise, the correlation between PSS with WP and IA with WP was (0.924); both were significant at a $1 \%$ level. The relationship between PSS and GC was (0.881 sig. 5\%), IA with GC was (0.903 sig. 1\%), and GC with WP (0.892 sig. 5\%). The higher levels of correlation justify the usage of path analysis rather than the multiple regressions. Therefore, the superiority of path analysis on multiple regressions when there are one or more mediating variables (Leach-Lopez et al, 2008; Hussein et al., 2016).

Table 3

The results of inter-correlations

\begin{tabular}{|c|c|c|c|c|}
\hline Variables & PSS & IA & $\mathrm{GC}$ & WP \\
\hline PSS & 1.00 & & & \\
\hline IA & $0.865^{* *}$ & 1.00 & & \\
\hline GC & $0.881 * *$ & $0.903 * * *$ & 1.00 & \\
\hline WP & $0.924 * * *$ & $0.924 * * *$ & $0.892 * *$ & 1.00 \\
\hline
\end{tabular}

Notes: $* * *$ and $* *$ indicates significant at $1 \%$ and $5 \%$ level by two-tailed tests; $\mathrm{n}=198$

\subsection{Results of path direct effect}

The results of the impact of the independent variables on the dependent variables through the path analysis equations are shown in table 4. A look into the table reveals that there is a low to moderate direct effect between the independent and dependent variables. For instance, the direct effect of PSS on WP was 0.107 (sig. at a 5\% level) which means participation in standardssetting enhances WP. Based on these results the results speak in the favor of accepting the first hypotheses. Likewise, the direct effect of PSS on GC was 0.208 (sig. 5\% level) and IA on WP was 0.217 (sig. 5\% level). This result is empirical evidence to accept the second hypothesis "IA has a positive relationship with WP". The rest were found significant at a $1 \%$ level, i.e. PSS on IA (0.331), the impact of IA on GC (0.444), and GC on WP (0.495). Again, the results speak in the direction of accepting the third hypothesis: "GC is positively related to WP". Despite the results having a low and moderate direct effect among the variables; the significant level cannot be ignored in all the cases. The value of $\mathrm{R}^{2}$ was found to be higher with one and two mediating variables, which indicates the explanatory effect of the mediating variables. For example, $\mathrm{R}^{2}$ was $(0.821)$ with no mediating variable, the value becomes higher (0.848) with only one mediating variable (IA). The value gets higher with two intervening variables (IA and GC) to reach 0.947. This indicates the more of the mediating variables the more the explanation power of the behavior of the dependent variable. The path analysis with direct effect relation is shown in Fig. 2.

\section{Table 4}

The results of direct effects

\begin{tabular}{|c|c|c|c|c|c|}
\hline Dependent variable & Independent variable & Direct effect & t-statistic & Sig. & $\mathrm{R}^{2}$ \\
\hline IA & PSS & 0.331 & 10.874 & 0.000 & 0.821 \\
\hline \multirow{2}{*}{$\mathrm{GC}$} & PSS & 0.208 & 8.782 & 0.021 & \multirow{2}{*}{0.848} \\
\hline & IA & 0.444 & 12.983 & 0.000 & \\
\hline \multirow{3}{*}{ WP } & GC & 0.495 & 16.777 & 0.000 & \multirow{3}{*}{0.947} \\
\hline & IA & 0.217 & 9.286 & 0.023 & \\
\hline & PSS & 0.107 & 5.228 & 0.048 & \\
\hline
\end{tabular}

Notes: $\mathrm{n}=198$; for each run of the regression model F-statistic is significant at $1 \%$ level 


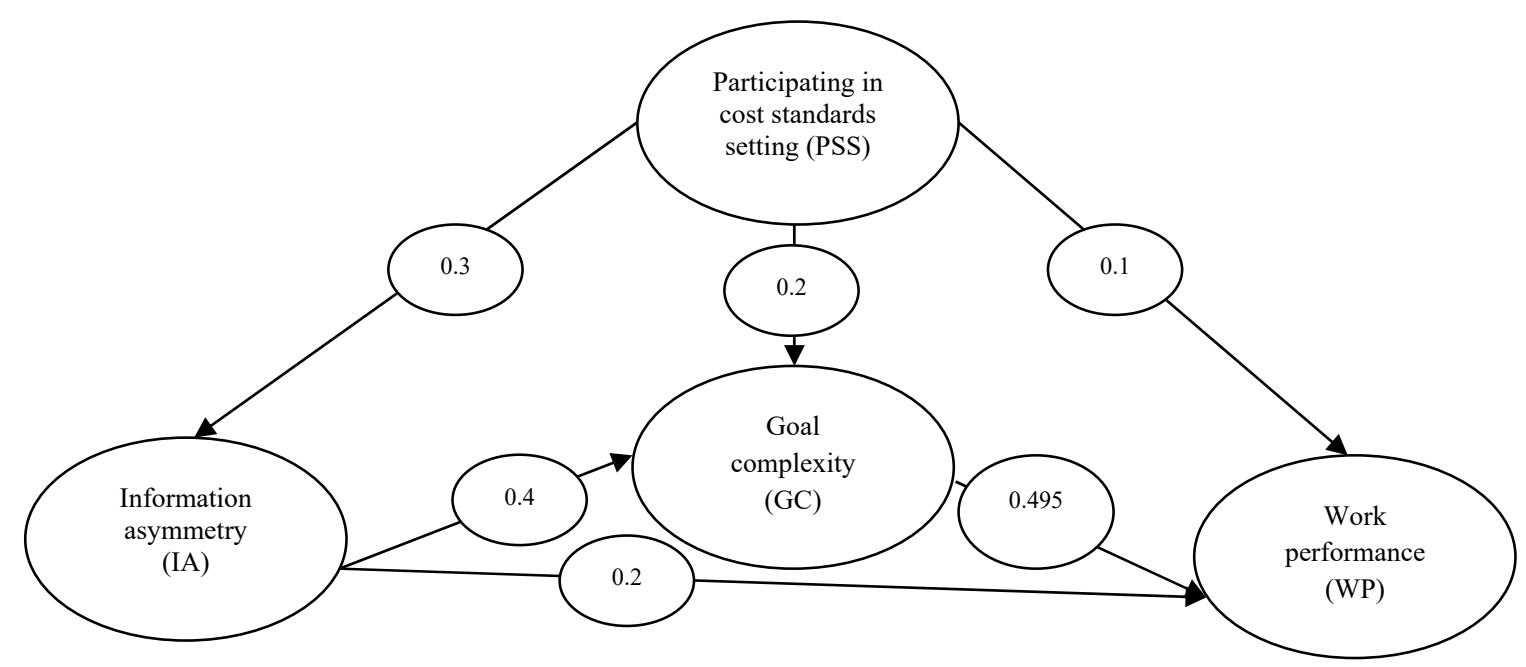

Fig. 2. direct effect of path analysis

\subsection{Direct, indirect, and spurious effect}

Path analysis explains the role of the independent variables on the dependent variables not only through the direct effect but extends through indirect and spurious effects. Table 5 shows the total effect, direct effect, indirect effect, and the spurious effect of path relations. The total effect was explained through the correlation values from table 3 and the direct effect value is from table 4. The calculation of the indirect effect of PSS on WP was through $(B \times C)+(D \times F)+(B \times E \times F)$. The spurious effect was calculated through total effect - (direct + indirect effect). It is noticed that there is an indirect effect for WP \& PSS (0.248), WP \& IA (0.217), and GC \& PSS (0.147). The first indirect effect was higher than the direct effect, which indicates that the impact was more through the mediating variables. Nevertheless, the next indirect effect (WP \& IA) was the same as the direct effect (0.217), the later indirect (GC \& PSS) effect was less than the direct effect. The spurious effect in the table is measured by the remaining from the total effect after eliminating both direct and indirect effects. In most of the cases, the spurious effect was responsible for 0.397 to 0.569 of the total effect, which indicates that more than 0.397 of the total effect was because another mediating variable should be taken into consideration or due to other factors related to sample size, several questionnaire forms analyzed or any non-considered factors.

Table 5

The results of indirect, and spurious effect

\begin{tabular}{|c|c|c|c|c|c|c|}
\hline \multicolumn{2}{|c|}{ Study Path } & \multirow{2}{*}{ Path abbreviation } & \multirow{2}{*}{ Total effect } & \multirow{2}{*}{ Direct effect } & \multirow{2}{*}{ Indirect effect } & \multirow{2}{*}{ Spurious effect } \\
\hline From & To & & & & & \\
\hline PSS & WP & $\mathrm{A}$ & 0.924 & 0.107 & 0.248 & 0.569 \\
\hline PSS & IA & B & 0.865 & 0.331 & -- & 0.534 \\
\hline IA & WP & $\mathrm{C}$ & 0.924 & 0.217 & 0.217 & 0.487 \\
\hline PSS & $\mathrm{GC}$ & $\mathrm{D}$ & 0.881 & 0.208 & 0.147 & 0.526 \\
\hline IA & $\mathrm{GC}$ & $\mathrm{E}$ & 0.903 & 0.444 & --- & 0.459 \\
\hline $\mathrm{GC}$ & WP & $\mathrm{F}$ & 0.892 & 0.495 & --- & 0.397 \\
\hline
\end{tabular}

Notes: total effect $=$ direct effect + indirect effect + spurious effect

The indirect effect of PSS on WP was calculated as $=\left(B^{*} C\right)+(D * F)+(B * E * F)$

\section{Conclusion}

The present work is a humble attempt to explain the role of participation in PSS on WP through the mediating effect of the role of IA and goal complexity. Data were collected from ten Iraqi companies working in the industrial sector namely Light Industrial Company, Alhilal Industrial Company, Iraqi Company for Manufacturing Cartons, Modern Painting Company, Modern Sewing Company, Iraqi Company for Carpet and Furniture, Iraqi National Company for Manufacturing Chemical and Plastic Materials, Pepsi Baghdad Company, Iron and Bicycle Company, Iraqi Company for Manufacturing and Exporting Dates. The analysis was based on 198 responses from the total 350, the rest of the forms had either missing data or were wrongly filled. To avoid bias in data collection, the researcher distributed the forms randomly to top management personnel, departmental managers, engineers, accountants, and administrators who are involved in setting cost standards. LSM path model was used for data analysis. The usage of the model was motivated by the works of (Leach-Lopez et al., 2008; Hussein et al., 2016). 
The study could measure the direct, indirect, and spurious effect of the role of PSS on WP. It is noticed that the direct effect of PSS on WP was 0.107 significant at a 5\% level. The impact was significantly higher by using IA (0.217) and was more by using both IA and GC as a mediating variable 0.495 at $1 \%$ significance level, which makes this path the most dominating path. The results, thus, confirm the importance of using both mediating variables in explaining the impact of PSS on WP. The results also confirm the positive and significant relationship between PSS and WP. It is, therefore, shown that the results stand with the first hypothesis by finding a positive and significant relationship between PSS and WP. Similarly, the second hypothesis was accepted through a positive and significant relationship between IA and WP. Likewise, the researcher accepts the third hypothesis by the significant and positive relationship between GC and WP. The result has the same direction as the findings of budget participation and managerial performance of (Leach-Lopez et al., 2008, 2009; Ozer \& Yilmaz, 2011; Odia, 2013; Mazzioni et al., 2014; Hussein et al., 2016; Sim \& Utami, 2018; Zainuddin \& Isa, 2019; Lunardi et al., 2020).

The result, therefore, suggests that firms should not overlook the role of participation in setting cost standards and exchange cost information between different levels in the organizational hierarchy to reduce IA and simplify GC then subsequently increase WP. The researcher suggests that the methodology and the study sample should be applied in different contexts and countries to generalize the findings of this paper. Despite its positive results, the study has a common limitation of other research papers that depend on primary data collection (questionnaire-based survey). Nevertheless, the value of Cronbach's $\alpha$ 's was 0.874 which provides evidence of a very low effect of the data reliability issue. The results could be more reliable and a chance of generalization by using more firms and higher responses from the Iraqi scenario or similar economic situation.

\section{Acknowledgement}

This paper was part of a visiting program in the Department of accounting, University of New Mexico, USA. The author would like to thank to Tikrit University and the Ministry of Higher Education and Scientific Research of Iraq for full support to complete the visiting program to the University of New Mexico of USA.

\section{References}

Ahn, T., Choi, Y., Hwang, I. and Hyeon, J. (2018). The Effect of Information Asymmetry and Participative Target Setting on Target Ratcheting and Incentives, public Performance \& Management Review, 41(3), 439-468.

Akerlof, G. (1970). The Market of Lemon: quality uncertainty and market mechanism.

Aranda, C., Arellano, J. and Davila, A. (2019). Subjective bonuses and target setting in budget-based incentive contracts. Management Accounting Research, 43, 45-60.

Berdicchia, D., \& Masino, G. (2019). The Ambivalent Effects of Participation on Performance and Job Stressors: The Role of Job Crafting and Autonomy. Human Performance, 32(5), 220-241.

Brownell, P. (1983) Leadership style, budgetary participation, and managerial behavior. Accounting, Organizations and Society, $8(4), 307-321$.

Chenhall, R., \& Brownell, P. (1988). The Effect of Participative Budgeting on Job Satisfaction and Performance: Role Ambiguity as an Intervening Variable. Accounting, Organizations and Society, 13(3), 225-233.

Cherrington, D. J., \& Cherrington, J. O. (1973). Appropriate reinforcement contingencies in the budgeting process. Journal of Accounting Research, 11(3), 225-253.

Curral, L., Leitao, P., Gomesa, C., Marques-Quinteiro, P. and Lind, P. (2017). How complexity leadership and cohesion influence team effectiveness. Revista Psicologia: Organizacoes e Trabalho, 17(4), 243-251.

Dakhli, A. (2010). Budgetary participation in a non-western country. The Journal of Business in Developing Nations, 12, 1-31.

De Faria, J., \& Da Silva, S. (2013). The effects of information asymmetry on budget slack: An experimental research. African Journal of Business Management, 7(13), 1086-1099.

Dunk, A. (1993). The effect of budget emphasis and information asymmetry on the relation between budgetary participation and slack. The Accounting Review, 68, 400-410.

Dusabe, M., Kule, \& Oluoch, J. (2016). Effect of asymmetric information on the performance of listed manufacturing companies. European Journal of Business and Social Sciences, 5(6), 342-352.

Eker, M. (2006). The Impact of Budget Participation on Managerial Performance via Organizational Commitment: A Study on the Top 500 Firms in Turkey. Ankara University SBF Dergisi, 64(4), 117-136.

Espedido, A., \& Searle, B. (2018). Goal Difficulty and Creative Performance: The Mediating Role of Stress Appraisal. Human Performance, 31(3), 179-196.

Fitoussi, D., MacCrory, F. and Pinsonneault, A. (2009). Information Asymmetry and the Productivity of Information Workers, Presentation delivered at Workshop on information systems and economics, Arizona. Retrieved from http://people.stern.nyu.edu/bakos/wise/ 2009/papers/wise2009-p11_paper.pdf on 22/8/2019.

George, A. (2001). The market for lemons. Quality uncertainty and the market mechanism. The Quarterly Journal of Economics, 84(3), 488-500. 
Hardin, A., Looney, C., Fuller, M., \& Schechtman G. (2013). Participative Goal Setting in Self-Directed Global Virtual Teams: The Role of Virtual Team Efficacy in Goal Setting Effectiveness and Performance, 46th Hawaii International Conference on System Sciences, Wailea, Maui, HI, 363-372.

Hassel, L.G., \& Cunningham, G.M. (2004). Psychic distance and budget control of foreign subsidiaries. Journal of International Accounting Research, 3(2), 79-93.

$\mathrm{Hu}, \mathrm{Y} .$, \& Yu, L. (2010). Investor Relations, Information Asymmetry and Corporate Performance. International Conference on E-Business and E-Government, Guangzhou, 2061-2064.

Hui, R., Sue-Chan, C., \& Wood, R. (2013). The Contrasting Effects of Coaching Style on Task Performance: The Mediating Roles of Subjective Task Complexity and Self-Set Goal. Human Resource Development Quarterly, 24(4), 429-458.

Hussein, S., Maji, S., \& Panda, N. (2016). the Association between Budget Goal Clarity and Managerial Performance in Iraqi Oil Refinery: The Role of Budget Goal Difficulty and Budget Participation. Middle East Journal of Management, 3(4), 343358.

James, O., \& Tonye, O. (2014). Information Asymmetry and Environmental Accounting: An Empirical View, International Journal of Managerial Studies and Research (IJMSR), 2(7), 101-116.

Jermias, J., \& Yigit, F. (2013). Budgetary Participation in Turkey: The Effects of Information Asymmetry, Goal Commitment, and Role Ambiguity on Job Satisfaction and Performance. Journal of International Accounting Research, 12(1), 29-54.

Jermias, J., \& Setiawan, T. (2008). the moderating effects of hierarchy and control systems on the relationship between budgetary participation and performance. The International Journal of Accounting, 43, 268-292.

Kalkanci, B., Chen, K., \& Erhun, F. (2011). Contract Complexity and Performance under Asymmetric Demand Information, An Experimental Evaluation, Management Science, 57(4), 689-704.

Kemei, J., \& Kerongo, F. (2014). The Effects of Information Asymmetry in the Performance of the Banking Industry: A Case Study of Banks in Mombasa County. International Journal of Education and Research, 2(2), 1-6.

Khalid, B., \& Hunjra, A. (2018). Measuring the validity of the instrument of information asymmetry, accounting information, personal values, investment satisfaction and investor decision: an empirical analysis of Pakistani stock exchanges. Journal of Policy Research, 1(1), 36-54.

Kozlowski, S., \& Hults, B. (1986). Joint moderation of the relation between task complexity and job performance for engineers, Journal of Applied Psychology, 71, 196-202.

Lau C., \& Eggleton I. (2003). The influence of information asymmetry and budget emphasis on the relationship between participation and slack. Accounting and Business Research, 33(2), 91-104.

Lau, C., \& Tan, S. (2003). The effects of participation and job-relevant information on the relationship between evaluative style and job satisfaction, Review of Quantitative Finance and Accounting, 21(1), 17-34.

Leach-López, M., Stammerjohan, W., \& Lee, K. (2009). Budget participation and job performance of South Korean managers mediated by job satisfaction and job-relevant information. Management Research News, 32(3), 220-238.

Leach-lópez, M., Stammerjohan, W., \& Mcnair, F. (2008). Effects of budgetary participation conflict on job performance of Mexican and US managers, Advances in Accounting, Incorporating Advances in International Accounting, 24(1), 49-64.

Lunardi, M. A., Zonatto, V. C. D. S., \& Nascimento, J. C. (2020). Mediating cognitive effects of information sharing on the relationship between budgetary participation and managerial performance. Revista Contabilidade \& Finanças, 31(82), 1432.

Machdar, N., Manurung, A., \& Murwaningsari, E. (2017). The Effects of Earnings Quality, Conservatism, and Real Earnings Management on the Company's Performance and Information Asymmetry as a Moderating Variable. International Journal of Economics and Financial Issues, 7(2), 309-318.

Mah'd, O., Al-Khadash, H., Idris, M., \& Ramadan, A. (2013). The Impact of Budgetary Participation on Managerial Performance: Evidence from Jordanian University Executives. Journal of Applied Finance \& Banking, 3(3), $133-156$.

Mahjoub, L. B., \& Halioui, K. (2012). The impact of Budget Participation on Organizational Performance via Competitiveness. International Journal of Contemporary Business Studies, 3(6), 38-49.

Man, D., \& Lam, S. (2003). The effects of job complexity and autonomy on cohesiveness in collectivistic and individualistic workgroups: A cross-cultural analysis. Journal of Organizational Behavior, 24, 979-1001.

Mazzioni, S., Politelo, L., \& Lavarda, C. (2014). Managers' Perception on Budget Participation, Procedural Justice and Managerial Performance. Sociedade, Contabilidade e Gestao, 9(2), 136-151.

Mia, L. (1989). The Impact of Participation in Budgeting and Job Difficulty on Managerial Performance and Work Motivation: A Research Note. Accounting, Organizations and Society, 14(4), 347-357.

Milani, K. (1975). The relationship of participation in budget-setting to industrial supervisor performance and attitudes: A field study. Accounting Review, 50( 2), 274-284.

Mowday, R., Porter, L., \& Steers, R. (1982). Employee-Organization Linkages: The Psychology of Commitment, Absenteeism, and Turnover. New York: Academic Press.

Murphy, K. (2000). Performance standards in incentive contracts. Journal of Accounting and Economics, 30 (3), $245-278$.

Nayyar, P. (1993). Performance Effects of Information Asymmetry And Economies of Scope in Diversified Service Firms. Academy of Management Journal, 36(1), 28-57. 
Nouri. H., \& Parker. R. (1998). the relationship between budget participation and job performance: the roles of budget adequacy and organizational commitment, Accounting, Organization and Society, 23((5/6)), 467-483.

Odia, J. (2013). Relationship between Budget Participation, Budget Procedural Fairness, Organizational Commitment, and Managerial Performance. Review of Public Administration and Management. DOI: 10.4172/2315-7844.1000138

Ostroff, C. (1992). the Relationship between Satisfaction, Attitudes, and Performance: An Organizational Level Analysis. Journal of Applied Psychology, 75, 963-974.

Owusu, E. E., Dwomoh, G., Collins, M., Yaa, G., \& Daniel, O. (2014). Assessing the Relationship between Budget Participation and Employees' Performance of Public Universities in Ghana: A Case of University of Education. International Journal of Academic Research in Accounting, Finance and Management Sciences, 4(1), 85-95.

Ozer, G., \& Yilmaz, E. (2011). Effects of Procedural Justice Perception, Budgetary Control Effectiveness and Ethical Work Climate on Propensity to Create Budgetary Slack. Business and Economics Research Journal, 2(4), 1-18.

Rachagan, S., Tong, J., Terpstra, R. and Mahenthiran, S. (2013). Intangible Factors Associated with Firm Performance in Developing Countries: Malaysian Retrieved from https://www.researchgate.net/publication/256048185_Intangible_Factors_Influencing_Firm_Performance_in_Developing Countries_Malaysian_Evidence on 22/01/2020.

Sim, S., \& Utami, W. (2018). Impact of budget participation on job satisfaction and employee performance with job relevant information (JRI). as an intervening variable, Jurnal Profita, 11(1), 81-90.

Tsui, J. (2001). The impact of culture on the relationship between budgetary participation, management accounting systems, and managerial performance: An analysis of Chinese and western managers, The International Journal of Accounting, 36(2), 125-146.

Venugopal, B. (2017). Homophily, Information Asymmetry and Performance in the Angels Market, Retrieved from https://ssrn.com/abstract=2981033 on January 08, 2020.

Wanous, J., \& Hudy, M. (2001). Single-item reliability: A replication and extension. Organizational Research Methods, 4, 361375

Waweru, N. M., Hoque, Z., \& Uliana, E. (2005). A survey of management accounting practices in South Africa. International Journal of Accounting, Auditing and Performance Evaluation, 2(3), 226-263.

Weinberg, R., Morrison, D., Loftin, M., Horn, T., Goodwin, E., Wright, E., \& Block, C. (2019). Writing Down Goals: Does It Actually Improve Performance?, The Sport Psychologist, 33, 35-41.

Welbourne, T., Johnson, D., \& Erez, A. (1998). The role-based performance scale: Validity analysis of a theory-based measure. Academy of Management Journal, 41, 540-555.

Yucel, R., \& Gunluk, M. (2007). Effects of Budgetary Control and Justice Perceptions on the Relationship between Budgetary Participation and Performance. Journal of Global Strategic Management, 1(2), 82-94.

Yuen, D., \& Cheung, K. (2003). Impact of Participation in Budgeting and Information Asymmetry on Managerial Performance in the Macau Service Sector, Journal of Applied Management Accounting Research, 1(2), 65-78.

Zacher, H., Heusner, S., Schmitz, M., Zwierzanska, M., \& Frese, M. (2010). Focus on opportunities as a mediator of the relationships between age, job complexity, and work performance. Journal of Vocational Behavior, 76, 374-386.

Zainuddin, S., \& Isa, C. (2019). The Role of Workplace Fairness and Information Sharing in a Budget Setting Process: An Empirical Study, Gadjah Mada International Journal of Business, 21(2), 135-158.

\section{Internet references}

https://globaledge.msu.edu/countries/iraq/memo(2016)

Business insider report by William Buiter https://www.businessinsider.com/fastest-growing-economies-2011-2

\section{Dear Respondent,}

In connection with my research work entitled "participation in cost standard-setting and work performance, the role of information asymmetry and goal complexity". May I please request you to kindly extend your cooperation in providing your response to the questions put in the questionnaire. Please answer all the questions following the instructions provided. Your responses will be treated as confidential and used exclusively for academic purposes. Your time and cooperation are very much appreciated.

Thank you!

PARTICIPATION IN COST STANDARD SETTING AND WORK PERFORMANCE, THE ROLE OF INFORMATION ASYMMETRY AND GOAL COMPLEXITY 


\section{Part A: General Information}

Name (optional)

Age. Gender Position (designation)

Educational Qualification

Total Length of service

Length of service in present position.

The name of your company.

\section{Part A: Goal Complexity}

Goal complexity refers to the extent, to which goals are stated specifically and clearly in the costing standards, and are understood by the unit managers responsible for meeting them. On the other hand, goals can vary from very loose and easily attainable to very difficult and unattainable. Please encircle (or tick) the proper number (against the following statements), which you think best indicates the level of clarity and difficulty of cost standards goals of your company.

Strongly Agree

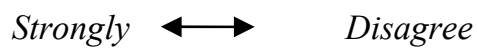

The cost standards goals of my company are specific and clear. I know exactly what the cost standards goals are.

I think the cost standards goals of my company are ambiguous and unclear. I do not know exactly what the cost standards goals are.

I understand fully which of the cost standards goals of my company are more important than others. I have a clear sense of priorities on the goals.

I do not have too much difficulty in reaching my cost standards goals. They appear to be fairly easy.

My cost standards goals are quite difficult to attain.

My cost standards goals require a great deal of effort from me to achieve them.

It takes a high degree of skill and know-how on my part to attain fully my cost standards goals.

I am always clear about what is necessary to perform well on my job.

I have adequate information to make optimal decisions to accomplish my performance objectives.

I can obtain the strategic information necessary to evaluate important decision alternatives.

\begin{tabular}{|c|c|c|c|c|c|}
\hline 1 & 2 & 3 & 4 & 5 & 6 \\
\hline 1 & 2 & 3 & 4 & 5 & 6 \\
\hline 1 & 2 & 3 & 4 & 5 & 6 \\
\hline 1 & 2 & 3 & 4 & 5 & 6 \\
\hline 1 & 2 & 3 & 4 & 5 & 6 \\
\hline 1 & 2 & 3 & 4 & 5 & 6 \\
\hline 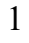 & 2 & 3 & 4 & 5 & 6 \\
\hline 1 & 2 & 3 & 4 & D & 6 \\
\hline 1 & 2 & 3 & 4 & 5 & 6 \\
\hline 1 & 2 & 3 & & & 6 \\
\hline
\end{tabular}

\section{Part B: participating in costing standards settings}


Cost standards participation is related to the involvement of managers in the cost standards process and their influence on the setting of cost standards targets. In this context please respond by encircling a number from 1 to 7 on the scale for each of the following items/questions.

am involved in cost standards goal setting

None of the standards

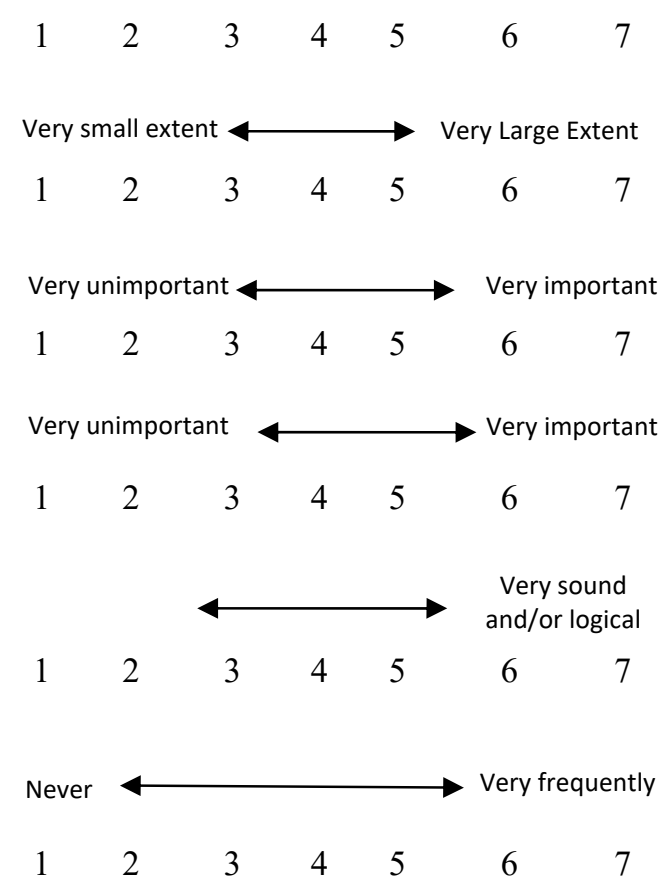

How often do you state your requests, opinions, and/or suggestions about the cost standard to your superior without being asked?

The reasoning provided by my superior in the matter of cost standard revisions is:

How important is your opinion in setting the targets in your cost standard?

My contribution to the formulation of the cost standard is:

How much influence do you feel you have on the final cost standard?

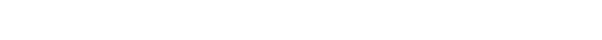

How often do you seek requests, opinions, and/or suggestions from your subordinates when the cost standard is being set?

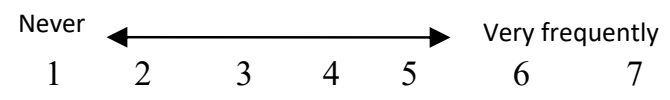

\section{Part C: The Role-Based Performance Scale}

1 to 5 Likert-type scale was used, with $1=$ Needs much improvement, $2=$ Needs some improvement, $3=$ Satisfactory, $4=$ Good, and $5=$ Excellent.

\section{JOB (doing things specifically related to one's job description)}

1. Quantity of work output.

2. Quality of work output.

3. Accuracy of work.

4. Customer service provided (internal and external).

CAREER (obtaining the necessary skills to progress through one's organization)

5. Obtaining personal career goals.

6. Developing skills needed for his/her future career.

7. Making progress in his/her career.

8. Seeking out career opportunities.

INNOVATOR (creativity and innovation in one's job and the organization as a whole)

9. Coming up with new ideas.

10. Working to implement new ideas.

11. Finding improved ways to do things.

12. Creating better processes and routines.

TEAM (working with coworkers and team members, toward the success of the firm)

13. Working as part of a team or workgroup.

14. Seeking information from others in his/her workgroup.

15. Making sure his/her workgroup succeeds.

16. Responding to the needs of others in his/her workgroup.

$\begin{array}{lllll}1 & 2 & 3 & 4 & 5 \\ 1 & 2 & 3 & 4 & 5 \\ 1 & 2 & 3 & 4 & 5 \\ 1 & 2 & 3 & 4 & 5 \\ & & & & \\ 1 & 2 & 3 & 4 & 5 \\ 1 & 2 & 3 & 4 & 5 \\ 1 & 2 & 3 & 4 & 5 \\ 1 & 2 & 3 & 4 & 5 \\ & & & & \\ 1 & 2 & 3 & 4 & 5 \\ 1 & 2 & 3 & 4 & 5 \\ 1 & 2 & 3 & 4 & 5 \\ 1 & 2 & 3 & 4 & 5 \\ & & & & \\ 1 & 2 & 3 & 4 & 5 \\ 1 & 2 & 3 & 4 & 5 \\ 1 & 2 & 3 & 4 & 5 \\ 1 & 2 & 3 & 4 & 5\end{array}$


ORGANIZATION (going above the call of duty in one's concern for the firm)

17. Doing things that help others when it's not part of his/her job.

18. Working for the overall good of the company."

19 . Doing things to promote the company.

20. Helping so that the company is a good place to be.

$\begin{array}{lllll}1 & 2 & 3 & 4 & 5 \\ 1 & 2 & 3 & 4 & 5 \\ 1 & 2 & 3 & 4 & 5 \\ 1 & 2 & 3 & 4 & 5\end{array}$

\section{Part D: information asymmetry}

Please choose a number against each statement, where: 1 (My superior has much better information); 7 (I have much better information)

1. In comparison with your superior, who owns better information regarding the activities undertaken in your area of responsibility?

2. In comparison with your superior, who is more familiar with the input-output relationships inherent in the internal operations of your area of responsibility?

3. In comparison with your superior, who is more certain of the performance potential of your area of responsibility?

4. In comparison with your superior, who is more familiar technically with the work of your area of responsibility?

5. In comparison with your superior, who is better able to assess the potential impact on your activities of factors external to your area of responsibility?

6. In comparison with your superior, who has a better understanding of what can be achieved in your area of responsibility?

$\begin{array}{lllllll}1 & 2 & 3 & 4 & 5 & 6 & 7 \\ 1 & 2 & 3 & 4 & 5 & 6 & 7 \\ 1 & 2 & 3 & 4 & 5 & 6 & 7 \\ 1 & 2 & 3 & 4 & 5 & 6 & 7 \\ 1 & 2 & 3 & 4 & 5 & 6 & 7 \\ 1 & 2 & 3 & 4 & 5 & 6 & 7\end{array}$

